УДК 2-1

DOI: $10.18101 / 1994-0866-2019-2-43-48$

\title{
ДЕСЕКУЛЯРИЗАЦИЯ И ТРЕНД ПОСТСЕКУЛЯРНОГО
}

\author{
(C) Багаева Ксения Анатольевна \\ кандидат философских наук, доцент \\ Бурятский государственный университет им. Д. Банзарова \\ Россия, 670000, г. Улан-Удэ, ул. Смолина, 24а \\ E-mail: ksyusha.81@mail.ru
}

В статье автор рассматривает особенности десекуляризации и формирование постсекулярного в мире и российском обществе. В статье указывается, что десекуляризация - это процесс, происходящий в общественных сферах, который ведет к формированию постсекулярного. Указаны уровни, в которых проходит десекуляризация, определены причины ее возникновения. Анализируются взгляды исследователей на секулярную эпоху. Постсекулярное является состоявшимся фактом современного мира, проявляясь в сфере сознания, коммуникации. Выявлены особенности взаимодействия религии и общества в условиях десекуляризации. Исследуя взаимодействие религии с образованием, политической сферой, экономикой, автор приходит к выводу, что принцип светскости в этих сферах утрачивает свое влияние. Сделано предположение об особенностях постсекулярного в России, что объясняется через одновременное существование светского и религиозного как в социальном бытии, так и в духовном.

Ключевые слова: религия; десекуляризация; постсекулярное; общество; религиозная организация; образование; экономика; политика.

\section{Для цитирования:}

Багаева К. А. Десекуляризация и тренд постсекулярного // Вестник Бурятского государственного университета. Философия. 2019. Вып. 2. С. 43-48.

Начиная с 90-х годов секуляризационный вектор общественного движения сменился, продолжившись процессом десекуляризации. Согласно терминологии Питера Бергера [1, с. 8-20], мир был секулярным и стал десекулярным, т. е. он вернулся в состояние до секуляризации. Однако, по мнению Юргена Хабермаса [2, с. 1-2], мир стал «постсекулярным», который рассматривается им в контекстепереосмысления отношения к религиозным организациям. Можно констатировать, что религия возвращается и изменяется. Приставки «де-» и «пост-» формируют термины, содержание которых различно потому, что десекуляризация несовместима с новыми тенденциями современного общества в том плане, что не включаема в дискурс постмодернизма. Скорее, десекуляризация выступает как подготовительный этап к постсекулярному. Сегодня у философов, религиоведов термин «постсекулярный» имеет больший успех, потому что в его рамках объяснимо современное внутреннее состояние религии. Десекуляризация также применима по отношению к религиозным институтам, организациям, связана с политикой и экономикой, образованием. Тогда как постсекулярное - это коммуникация, мышление, реальность, возникающие в результате десекуляризации. Соответственно, в статье будет применяться как термин «десекуляризация», так и «постсекулярный». 
Относительно постсекулярного общества Ю. Хабермас писал, что «этот небесспорный термин может быть применен только к высокоразвитым обществам Европы или таким странам, как Канада, Австралия и Новая Зеландия, где религиозные связи между людьми ослаблялись на протяжении длительного времени, но особенно резко в послевоенный период... при этом религиозное поведение и религиозные убеждения населения этих государств не изменились за последние годы до такой степени, чтобы можно было назвать эти общества «постсекулярными» [2, с. 1-2]. Прошедший процесс секуляризации в России привел к десекуляризации.

В этом контексте несколько иную точку зрения высказывает исследователь С. А. Королев. По его мнению, в 1980-1990-х гг. в России произошла не десекуляризация, а утверждение европоморфной модели секуляризованного светского общества, где религия является всего лишь одной из его подсистем». Что верно, поскольку европейская секуляризация стала причиной освобождения религии, тогда как в России свободной стала благодаря десекуляризации [3]. По существу, советская власть в конце 80-х - начале 90-х гг. прошлого века последовательно проводила антирелигиозную политику. После распада Советского Союза конфессии получают свободу, поддерживают новую власть. Высвободились внутренние силы религии, которые были скрыты до этого. Десекуляризация привела к формированию постсекулярности. Постсекулярное общество - это общество, наступающее после секулярного, которое сегодня в российском обществе уже реальность.

Религия становится частью публичной и приватной сфер. Постсекулярность приводит к изменению в обществе и в самих религиозных организациях. Одним из таких примеров является обмирщение церкви. Косвенно это подтверждает А. Шишков, указывая, что обмирщение религии становится закономерным процессом, который возникает из-за взаимодействия религиозной и светской сфер, оказывая влияние друг на друга. Когда религия была оторвана от общества, то не имела возможности взаимодействовать с другими сферами. Как только религия входит в публичную сферу, изменения становятся очевидны [4, с. 174].

Еще одним подходом является предлагаемая К. Добеллером модель секуляризации, состоящая из трех уровней. Первый уровень - макроуровень - секуляризация общества. На втором - мезоуровне - секуляризации подвергаются религиозные организации. Наконец, на третьем - микроуровне - происходит секуляризация индивидуального сознания [5]. По такому принципу, как предполагается, проходит десекуляризация как обратный процесс секуляризации. Десекуляризация приводит к присутствию религии на указанных уровнях.

Увеличение верующих либо тех, кто позиционирует себя в качестве таковых, свидетельствует о десекуляризации на микроуровне. Отмечаются изменения в общественном сознании по отношению к религии. Интерес к религии как к культурно-историческому наследию, ценностному основанию увеличили рост доверия к религиозным институтам. Показателем этого является рост количества религиозных организаций в России. На 1992 г. в России число зарегистрированных религиозных организаций было 4 846, тогда как к 1995 г. их стало 11532. По данным Министерства юстиции Российской Федерации на 22.04.2019 г., религиозных организаций насчитывается $30896^{1}$. Рост числа подтверждает присутствие

${ }^{1}$ URL: www.gks.ru/bgd/regl/b15_11/IssWWW.exe/Stg/d01/11-03.htm (дата обращения: 20.03.2019). 
религии на мезоуровне. Кроме того, опрос Левада-центра, проведенный 1215 февраля 2016 г., выявил, что 56\% сегодня удовлетворены отношениями светского и религиозного, однако в то же время $31 \%$ респондентов считают, что российские власти должны руководствоваться в своих действиях религиозными убеждениями, 24\% - что церковь должна оказывать влияние на принятие государственных решений ${ }^{1}$.

На мезоуровне фиксируется рост религиозной монополии. Актуальное расположение религиозных организаций в российском обществе представляется в иерархической последовательности. На самом верху находится Русская православная церковь. Ниже представлены другие традиционные религии (ислам, буддизм, иудаизм). Далее те религии, что действуют на территории страны более 15 лет. Низшую ступень занимают религиозные организации, не зарегистрированные официально. Четырехступенчатое расположение конфессий можно уменьшить до двух. В данном случае по нисходящей на первой ступени традиционные конфессии, на второй - нетрадиционные. Но в любом случае наиболее значительное место занимает Русская православная церковь как религия государствообразующего народа.

Следует отметить, что в трехуровневой схеме К. Доббелера уровни находятся в постоянном взаимодействии друг с другом. Так, процессы десекуляризации на макроуровне активизируют микро уровень, что и произошло в России в конце XX в.

Продолжая мысль о десекуляризации в России, отметим, что, по мнению Ю. Ю. Синелиной, изменения в религиозной сфере представляют собой движение маятника, колебания которого идут от секуляризации к десекуляризации. «Это воспроизводящаяся модель изменения религиозного мировоззрения; позволяет автору говорить о цикличности процесса секуляризации в России» [6, с. 304].

И сегодня, следуя логике вышеуказанных воззрений, видны предпосылки нового цикла секуляризации в связи с глобализацией и трансформациями в мировом и российском обществе. Получается, что движение маятника запускает процесс дескуляризации, который приводит к формированию постсекулярного мира

Соответственно, как бы ни интерпретировался тот процесс: как движение маятника или переход от секулярного мира к постсекулярному, так или иначе тенденции десекуляризации в российском обществе, приводящие к формированию постсекулярного, очевидны.

Итак, одновременно в конце XX в. наблюдается антагонистичная секуляризации тенденция «религиозного ренессанса», т. е. десекуляризация и последующая ресакрализация как российского общества, так и западного мира. Этот процесс охватил США, Европу, азиатские страны, исламские государства, постсоветское пространство.

На рубеже веков либерализм, атеизм утратили свои позиции с точки зрения многих государств. Западные страны сполна ощутили на себе воздействие традиционной мусульманской культуры, практически не поддающейся аккультурации. Эти страны были вынуждены поменять демократическую позицию в тот момент, когда столкнулись с усилением исламской религиозности в отдельно взятых западных государствах. Ранее секулярированное европейское общество

1 Церковь и государство [Электронный pecypc]. URL: http://www.levada.ru /2016/02/19/ tserkov-i-gosudarstvo-2 (дата обращения: 20.03.2019). 
оказалось в ситуации, когда религиозное не просто вытесняет светское на периферию, a, скорее, окрашивает светские области религиозным. Это проявляется тенденция к постсекулярности, возникают новые религиозные смыслы, актуальные для светского пространства, светское уже не может конкурировать с религиозным. В России складывается несколько иная ситуация, когда традиционные религии во главе с государство образующей Русской православной церковью являются гарантом толерантного существования в обществе, но тем не менее отметим, что мир переживает возрождение религии, или возвращение религии, процесс, охвативший не только культуру, но и государственную идеологию.

Философы разных направлений говорили о закате религии, неправильности ее взглядов. Например, марксизм предупреждал, что религиозное отражение мира может исчезнуть. И у них были все основания следовать такому мнению, потому что европейская секуляризация с XVIII в. явно вела к дальнейшему исчезновению религии. Однако конец XX в. отчетливо показал, что религия не только остается, но и возрождается. Увеличивается число религиозных движений на арабском Востоке, Восточной Европе, в том числе в России.

Религиозные организации играют все большую роль в современном обществе. Оказалось, что светские ценности не всегда могут дать ответы на возникающие вызовы современности, поэтому религиозные ценности находят поддержку в обществе.

Одним из важных факторов, повлиявших на процесс десекуляризации, стала глобализация, которая привела к потере национальной и этнической самобытности. Тогда как религия становится гарантом сохранения для народа национальной и этнической идентичности. Поэтому можно глобализацию определять как один из факторов, приведших к десекуляризации. Такая точка зрения также имеет последователей среди философов. Еще английский исследователь А. Тойнби видел в религии фактор цивилизационных сдвигов, именно религия лежит в основе развития цивилизации. Связывается это с тем, что общество всегда стремится к устойчивым ценностям, а религия - это самая устойчивая сфера культуры.

Следует сказать, что в каждой стране десекуляризация проходила поразному. Это зависело от степени влияния религии на образ жизни народа, его менталитет, культуру, национальное самосознание, государственность. Поэтому общемировая тенденция десекуляризации проявляется по-своему в зависимости от религиозных традиций, а формирование постсекулярного общества проходит в различной динамике.

Религия проникает в ключевые сферы деятельности человека: политику, экономику, образование. Одной из важнейших сфер общества, которая подверглась десекуляризации, стала политическая сфера. Сегодня наблюдается ситуация, когда религия может влиять на общественно-политические процессы. И это происходит, несмотря на заявленное требование руководителей конфессий следовать принципу светскости. По существу, религия легитимизирует моральные ценности в обмен на партнерство со стороны государственной власти. Религиозные деятели являются активными челнами Общественной палаты РФ, религиозные деятели, в частности, патриарх Русской православной церкви, высказываются о межнациональных отношениях, социальном или экономическом положении. Причем такие действия со стороны религиозных организаций одобряемы боль- 
шинством российского общества. Таковы данные, полученные Левада-центром: почти $71 \%$ опрошенных одобряют деятельность патриарха Кирилла ${ }^{1}$.

Очевидно также, что религия сейчас - часть образования. Считается, что светское образование не должно быть каким-либо образом связано с религией. Школы, колледжи или университет не должны подчиняться религиозным организациям. Естественно, исключая внутриконфессиональное образование, цель которого заключается в воспроизводстве служителей культа. Однако сложившаяся ситуация свидетельствует о том, что религиозные организации посредством внедрения в школьный курс «Основы религиозной культуры и светской этики» не напрямую, но все же воздействуют на неокрепшие умы и мировоззрение младших школьников. Тем самым нарушается принцип светскости образования, потому что известно, что членами методических советов, рекомендующих учебники, являются священнослужители. Кроме того, религиозные организации становятся частью светского пространства.

Существенным аспектом постсекулярности является внедрение религии в экономику. Так сложилось, что религиозные организации исторически вели хозяйственную деятельность. Однако сегодня наблюдается формирование так называемой церковной экономики, когда реализуются товары религиозного, культового назначения, осуществляются услуги религиозного характера, выполняются обряды на коммерческой основе. Причем, как утверждает Ж. Т. Тощенко, «велика доля так называемой побочной деятельности, и средства от нее могут быть весьма значительными...» [7].

По существу, постсекулярный мир приводит к созданию ситуации религиозного рынка, когда религии находятся в состоянии конкуренции друг с другом, они борются за последователей. Таким образом, религиозные организации - это участники экономического пространства. Законы рынка влияют на них, определяют стремление приобретать религиозные услуги в обществе. Менее конкурентно способные покидают религиозный рынок, более сильные остаются. В этом отношении религиозный плюрализм выгоден обществу, что позволяет избавится от ненужных организаций, но, с другой стороны, создает более сложные условия для конкуренции.

Все указанное приводит к тому, что церквям и ее деятелям приходится участвовать в политических акциях, социальных проектах, создавать партии, СМИ. Конечно, десекуляризация не безгранична, даже следуя логике маятникового движения: от секуляризации к десекуляризации и обратно. В скором времени должно начаться возвратно-поступательное движение к секуляризации. Возникнут новые проблемы, которые религиозные институты не смогут решить. Внутри самих конфессий начинаются внутренние конфликты и расколы. Тем более, что в исламских государствах десекуляризация проходит под фундаменталистскими идеями возвращения к традиционным истокам. Но постсекулярность все еще актуальна, потому что секулярное ушло, но после него что-то осталось и этим что-то становится постсекулярное.

Обращаясь к религиозной ситуации в российском обществе, укажем, что процесс десекуляризации идет во всех сферах. Сегодня отмечается усиление влияния

1 Церковь и государство [Электронный pecypc]. URL: http://www.levada.ru/ 2016/02/19/tserkov-i-gosudarstvo-2 (дата обращения: 20.03.2019). 
религии, но при постулируемом светском характере общества. Это означает изменение в общественном сознании, рост религиозности, увеличивается количество религиозных организаций, как традиционных, так и нетрадиционных, исчезновение границ принципа свободы совести, внедрение религии в политику, образование и экономику. При этом наблюдается одновременное сосуществование секулярного и религиозного. Это уникальная ситуация, проявляющаяся в таких контекстах: социальном бытии и в антропологическом. Получается, что религия занимает место не только в духовном мире человека, но и в его социальном существовании. Поэтому, исходя из культурно-исторических, ментальных, духовных особенностей религии России, хочется, чтобы именно они стали в постсекулярном мире не обмирщенными религиозными институтами, а духовной силой.

Литература

1. Бергер П. Фальсифицированная секуляризация // Государство, религия, церковь в России и за рубежом. 2012. № 2. С. 8-20.

2. Хабермас Ю. Постсекулярное общество - что это? Часть первая // Российская философская газета. 2008. № 4(18). С. 1-2.

3. Королев С. А. Секуляризация и десекуляризация в контексте псевдоморфного развития России [Электронный ресурс] // Философская мысль. 2015. № 4. C.1-54. URL: http://enotabene.ru (дата обращения: 30.01.2019).

4. Шишков А. Некоторые аспекты десекуляризации в постсоветской России // Государство. Религия. Церковь в России и за рубежом. 2012. № 2(30). С. 174.

5. Dobbelaere K. Secularization: a Multi-Dimensional Concept// Current sociology. 1981. V. 29.

6. Синелина Ю. Ю. Циклический характер процесса секуляризации в России (социологический анализ: конец XVIII — начало XXI в.): дис. ... д-ра социол. наук. М., 2009. С. 304.

7. Тощенко Ж. Т. Экономические притязания религии [Электронный ресурс]. URL: http://www.gazetaprotestant.ru_(дата обращения: 30.01.2019).

\section{DESECULARIZATION AND THE TREND OF POSTSECULAR}

\section{Kseniya A. Bagaeva}

Cand. Sci. (Philos.), A/Prof.,

Dorzhi Banzarov Buryat State University

24a Smolina St., Ulan-Ude 670000, Russia

E-mail: ksyusha.81@mail.ru

The article considers the features of desecularization and development of postsecularism in the world and Russian society, highlights the features of this process in the world and Russian society. Desecularization is a process occurring in public spheres, which leads to the development of postsecular. We have analyzed the views of researchers on the secular era, and described the levels at which desecularization takes place, and the reasons for its occurrence. The postsecular is a fact of the modern world, manifesting in the sphere of consciousness, communication. The article reveals the features of religion and society interaction in the conditions of desecularization. Investigating the interaction of religion with education, policy, and economy, we come to the conclusion that the principle of secularism loses influence in these spheres. The features of postsecularism in Russia are the simultaneous existence of the secular and the religious both in social and spiritual life.

Keywords: religion; desecularization; postsecular; society; religious organization; education; economy; policy. 